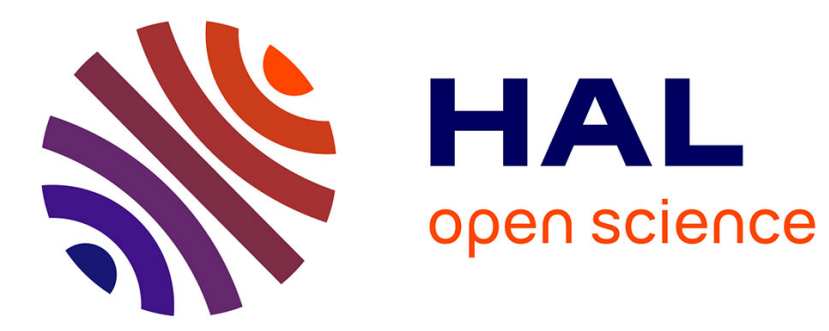

\title{
Diet of coastal foraging Eurasian otters ( L.) in Pembrokeshire south-west Wales
}

\author{
Gareth S. Parry, Sue Burton, Bethan Cox, Dan W. Forman
}

\section{To cite this version:}

Gareth S. Parry, Sue Burton, Bethan Cox, Dan W. Forman. Diet of coastal foraging Eurasian otters ( L.) in Pembrokeshire south-west Wales. European Journal of Wildlife Research, 2010, pp.485-494. 10.1007/s10344-010-0457-y . hal-00633606

\section{HAL Id: hal-00633606 https://hal.science/hal-00633606}

Submitted on 19 Oct 2011

HAL is a multi-disciplinary open access archive for the deposit and dissemination of scientific research documents, whether they are published or not. The documents may come from teaching and research institutions in France or abroad, or from public or private research centers.
L'archive ouverte pluridisciplinaire HAL, est destinée au dépôt et à la diffusion de documents scientifiques de niveau recherche, publiés ou non, émanant des établissements d'enseignement et de recherche français ou étrangers, des laboratoires publics ou privés. 


\title{
Diet of coastal foraging Eurasian otters (Lutra lutra $L_{\text {.) }}$ in Pembrokeshire south-west Wales
}

\author{
Gareth S. Parry • Sue Burton • Bethan Cox • \\ Dan W. Forman
}

Received: 5 July 2010 /Revised: 29 September 2010 /Accepted: 1 October 2010 / Published online: 19 October 2010

(C) Springer-Verlag 2010

\begin{abstract}
The importance of the marine environment to Eurasian otters is currently poorly understood. Wales is one of the few countries where coastal activity has been recorded and an increase in marine otter sightings could indicate remarkable developments within Welsh populations. The trophic niche of coastal otter populations around Pembrokeshire was investigated over a 12-month period. Marine activity was more widespread than previously thought and marine prey formed the largest component of otter diet, although, otters also consumed freshwater and terrestrial prey throughout the year. Otter diet was very diverse compared to other European coastal populations and a spring contraction in trophic niche width coincided with the estimated timing of breeding activity. Seasonal variation in prey composition was predominantly due to differences in the consumption of alternate prey types. In
\end{abstract}

Communicated by C. Gortázar

G. S. Parry $\cdot$ D. W. Forman $(\bowtie)$

Department of Pure and Applied Ecology,

Conservation Ecology Research Team,

School of the Environment and Society, Swansea University,

Singleton Park,

Swansea SA2 8PP, UK

e-mail: d.w.forman@swansea.ac.uk

\section{S. Burton}

Pembrokeshire Marine SAC officer, The Old Sail Loft,

Milford Docks,

Milford Haven, Pembrokeshire SA73 3AF, UK

B. Cox

Pembrokeshire Biodiversity Partnership Implementation Officer, c/o Development Planning, Pembrokeshire County Council, County Hall, Freeman's Way,

Haverfordwest, Pembs SA61 1TP, UK areas where wetlands are fragmented and populations of freshwater fish are declining, the marine environment may become an increasingly important habitat for otters. It is necessary to define the historical importance of coastal populations to otter conservation. Coastal areas are often subject to pressure from human activities, so the impact of disturbance needs to be assessed. Importantly, there is no verified otter survey method for coastal areas, so the use of marine habitat is likely to be underestimated.

Keywords Eurasian otter · Diet · Coastal · Marine · Foraging · Carnivore

\section{Introduction}

The Eurasian otter Lutra lutra (hereafter referred to as the otter) is a semi-aquatic carnivore belonging to the Mustelid family. In many areas of Europe and Asia, otters remain a species of conservation concern following widespread population declines during the 20th century (Ruiz-Olmo et al. 2008). The otter is one of only a few Eurasian carnivores that has evolved the ability to actively forage both in water and on land (Oliveira et al. 2008), and is highly capable of hunting in both freshwater (Carss et al. 1990; Copp and Roche 2003) and marine (Kruuk and Moorhouse 1990; Heggberget 1993) environments. A considerable amount of research has been undertaken on otter diet in freshwater habitats across Europe. In contrast, only a few studies have examined otter diet and behaviour in coastal regions. Research carried out in Scotland since the 1970s elucidated a number of fascinating aspects of the otter's ability to forage in marine waters (e.g. Watson 1978; Kruuk et al. 1987; Kruuk and Moorhouse 1990; Watt 1995), whilst researchers in Norway (Heggberget 1993), Portugal (Beja 
1991), Eire (Kingston et al. 1999) and Spain (Clavero et al. 2004) have described various aspects of otter trophic ecology in coastal areas. Very little information is available from coastal otter populations in other areas (Britton et al. 2006; Liles 2003a); consequently, the prevalence of marine activity within this species' European range is currently poorly defined.

Further investigation is required to determine the significance of coastal habitats to the ecology and conservation of otter populations. Moreover, there is little published information on UK otter populations outside of Scotland, despite declines being more severe in Wales (Jones and Jones 2004) and England (Crawford 2003). The coastline of South Wales provides a wealth of opportunities for otters, with large sections of remote or inaccessible coastline that provide potential foraging, resting and breeding sites (Liles 2003a). It is known that otters are widely distributed in Pembrokeshire (Jones and Jones 2004) and preliminary surveys have indicated that otters are utilising coastal areas for foraging and breeding at some locations (Liles 2003a). Accordingly, Pembrokeshire may represent one of the most important areas for otters in Wales, but very little is known about the ecology of the otter population in this region. The Pembrokeshire coast is subject to concurrent conservation and human economic interest. The presence of oil refineries in Milford Haven means that there is also a risk of crude oil spillage, whilst the Pembrokeshire coast has also been identified as a potential site for renewable energy development (Project Management Support Services 2006). Thus, the extent to which otters use marine habitats in Pembrokeshire needs to be determined, so that potential conflict with human industrial and recreational activities can be assessed and incorporated into conservation management plans.

Trophic niche describes the way an organism utilises food resources within its environment (Begon et al. 1996). It is important to study carnivore trophic niches as this determines the fitness of populations and their role in the trophic interactions of food webs (Miller et al. 2001). Dietary data is typically reported using parameters such as niche width, which describes the diversity of prey taken (Sargeant 2007). This study describes the trophic niche of otters inhabiting coastal areas of Pembrokeshire over a 12-month period, addressing three specific aims (a) to determine the extent to which otter populations in Pembrokeshire are using the marine environment and (b) to record the temporal variation in the dietary composition and population total trophic niche width (TNW) of costal otters in Pembrokeshire. (c) Calculate the TNW using data from previous studies conducted in coastal areas of Europe (see Appendix A for a full list of sources included) to provide an overview of the degree of dietary generalisation or specialisation in coastal foraging otter populations.

\section{Materials and methods}

Study area

The Pembrokeshire Coast National Park covers $416 \mathrm{~km}$ of coastline and contains the Pembrokeshire Marine Special Area of Conservation (SAC), one of the largest European Marine Sites in the UK. This encompasses several Special Protection Areas (SPA), Wales' only Marine Nature Reserve and many Sites of Special Scientific Interest. Two of the sampling sites fell within the St David's Peninsula Coast SPA. The Pembrokeshire coastline is heterogeneous including rocky shores, sandy shores, sub-tidal reefs, mudflats, estuaries, lagoons and salt marsh. In places, there are steep cliffs and coastal caves. Many rivers and small streams discharge into the sea along the width of the Pembrokeshire coast, most of which are less than $2 \mathrm{~km}$ long (Liles 2003a). The Pembrokeshire coast also contains number of large shallow inlets and bays which slope out gradually from the coast providing a shallow foraging habitat for otters. A number of sampling sites were located within the Milford Haven waterway (Fig. 1), which is also a part of the Pembrokeshire Marine SAC. Pembrokeshire is picturesque and a popular tourist destination, whilst Milford Haven is a busy port used for both industry and leisure purposes.

\section{Spraint collection and dietary analysis}

Spraint collections were undertaken by a team of volunteers co-ordinated by the Pembrokeshire Marine SAC officer and Pembrokeshire Biodiversity Partnership Implementation Officer. The aim was to visit a total of 21 confirmed sprainting sites (Fig. 1) every month between July 2007 and June 2008. Volunteers were trained by the Pembrokeshire Marine SAC Relevant Authorities Group and Pembrokeshire Biodiversity Partnership to help them identify and collect spraints. During each monthly visit, the volunteers were instructed to search the immediate vicinity of the site and collect up to three spraints for analysis. A three-spraint limit was set as this enabled a year-long study to be undertaken with the logistical and financial resources available. In some cases, this meant that only a sub-set of the available spraints were analysed; however, in many cases, less than three spraints were present. Spraints were placed into individual, sealed and labelled bags and sent to Swansea University where they were stored at $-17^{\circ} \mathrm{C}$ until dietary analysis was undertaken. The criteria for samples to be included in the dietary analysis were that each bag must contain a single spraint. All spraint bags returned were checked to confirm that they contained a single otter spraint. In the event of rejected samples, the reason was recorded. Red fox Vulpes vulpes, American mink Mustela vison and European polecat 
Fig. 1 The Pembrokeshire coast with stars indicating sampling sites and circles indicating towns (produced using MapInfo Professional(C) Pitney Bowes Software Inc New York USA) using an OS-base map obtained from EDINA $C$

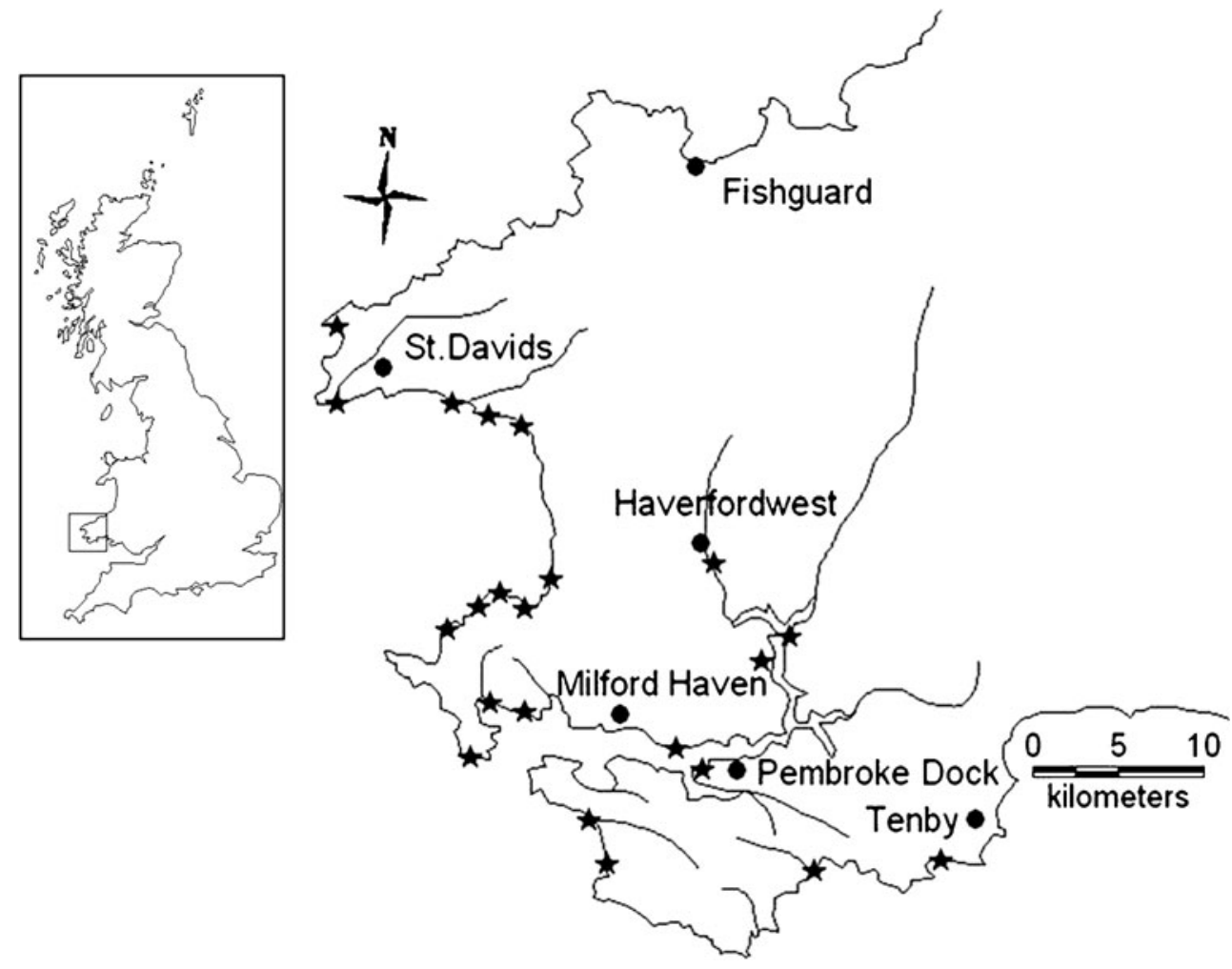

Mustela putorius are present in Pembrokeshire (NBN 2010) and may use coastal areas. Scats from these species are relatively easy to distinguish from otter spraints and a recent molecular study verified the primary author's ability to accurately identify otter spraints (Forman et al., unpublished data).

Otter diet was determined through the identification of hard prey remains in spraints. Prior to analysis, spraints were soaked individually in $250-\mathrm{ml}$ beakers containing a saturated solution of biological detergent for a period of at least $24 \mathrm{~h}$. The spraints were then rinsed through a $420-\mu \mathrm{m}$ sieve and turned out onto a sheet of paper roll, with care taken to ensure that all remains were removed from the sieve. The spraint remains were left to dry for a period of at least $24 \mathrm{~h}$. All spraints were analysed using an Olympus SZ40@ dissection microscope (Olympus UK Ltd, Watford). Prey remains were indentified using published keys (Day 1966; Watson 1978; Miranda and Escala 2002; Conroy et al. 2005) and a reference collection containing vertebrae and mouth parts of 39 fish species, three amphibian species and two reptile species. Where possible, remains were identified to family or species level.

The results of the dietary analysis were expressed using the Relative Frequency of Occurrence (RFO\%) method described by Watson (1978) as

$\mathrm{RFO} \%=\frac{\text { Number of occurrences of a prey category }}{\text { Sum of occurrences of all preycategories }} \times 100$
The limitations of using spraint analysis to study diet are well documented (Carss and Elston 1996; Carss and Parkinson 1996). The relative frequency of occurrence method has been shown to produce a relatively accurate interpretation of diet by feeding trials on captive otters (Erlinge 1968; Carss and Parkinson 1996; Jacobsen and Hansen 1996). In order to determine the extent of marine foraging the proportions of marine fish, freshwater fish and non-fish prey in otter diet were assessed. Fish prey was classified as marine or freshwater using the classifications of Wheeler (1969). A full year of spraints was only available from one site, severely reducing the power of statistical analysis of spatial trends in diet. Consequently, a spatial analysis was not undertaken.

Data analysis

All analyses were conducted using SPSS 13.0 (SPSS Inc, Chicago, USA). Prior to analysis, the distribution of all data were assessed using a Kolmogorov-Smirnov test and the equality of variance tested using a Levene's test. Significance $(p)$ was set at 0.05 . Population TNW was calculated using the Shannon-Wiener standardised measure $\left(H^{\prime}\right)$, described by Krebs (1989) as

$H^{\prime}=\Sigma P j \log e P j$

$\mathrm{Pj}=$ Proportion of individuals found in or using a resource states 
Variation in proportion of marine and freshwater prey and seasonal variation in TNW was investigated using oneway analysis of variance (ANOVA). Seasonal variation in dietary composition was investigated using Renkonen's index of percentage similarity, described by Krebs (1989) as

$P=\%$ $\operatorname{minimum}\left(P_{1 \mathrm{i}} P_{2 \mathrm{i}}\right)$

$P=$ Percentage of similarity between sample 1 and 2

$P_{1 \mathrm{i}}=$ Percentage of species in community 1 sample

$P_{2 \mathrm{i}}=$ Percentage of species in community 2 sample

The top ten prey types were determined using the overall RFO\% values. To reduce discrepancies caused by using many different levels of taxonomic classification fish were grouped to family level, with the exception of flatfish which is routinely grouped as an order in otter dietary studies (Watson 1978; Kruuk and Moorhouse 1990; Watt 1995; Kingston et al. 1999). Non-fish prey were organised to class level, as is normal practice in otter dietary studies. The top ten prey types were then used to investigate seasonal variation in diet composition through one-way ANOVA. Where significant results were detected, a least significant difference post hoc test was applied to investigate which pairings differed significantly.

\section{Results}

Distribution and habitat use of coastal otters

in Pembrokeshire

Otter spraints were successfully collected at all study sites and there was evidence that use of marine, freshwater and terrestrial habitats was widespread. Non-fish prey was recorded at $66.7 \%(14 / 21)$ of sites, whilst both marine and freshwater prey was recorded in spraints at $76.2 \%(16 / 21)$ of sites, including sites situated well within the estuary. Interestingly, spraints containing only prey originating from marine habitats were recorded at just $14.3 \%(3 / 21)$ of sites. Two sites returned no samples that passed the inclusion criteria.

Trophic niche and temporal variation in diet

In total, 232 spraints were collected of which 180 passed the criteria to be included in the dietary analysis. The most frequent reason for rejection was the presence of multiple spraints in one bag. There were 578 prey occurrences and 30 different prey types were identified. Fish constituted $85.3 \%$ of the overall RFO\% (Table 1). Sticklebacks (12.8\%), gobies $(12.5 \%)$, eels $(10.9 \%)$ and blennies $(10.4 \%)$ were the most frequent prey items overall. Crustaceans (6.6\%),
Table 1 Otter diet on the Pembrokeshire coast July 2007-June 2008 expressed as relative frequency of occurrence (RFO\%)

\begin{tabular}{|c|c|c|}
\hline Prey type & Taxonomic name & $\mathrm{RFO} \%$ \\
\hline Fish & & 85.3 \\
\hline Freshwater fish & & 29.3 \\
\hline Bullhead & Cottis gobio & 2.4 \\
\hline Chub & Leuciscus cephalus & 0.5 \\
\hline European eel & Anguilla anguilla & 10.9 \\
\hline Minnow & Phoxinus phoxinus & 0.2 \\
\hline Pike & Esox lucius & 0.2 \\
\hline Salmonidae & Salmonidae sp & 2.8 \\
\hline Three-spined stickleback & Gasterosteus aculeatus & 6.6 \\
\hline Unidentified Cyprinidae & Cyprinidae sp & 5.7 \\
\hline Marine fish & & 55.7 \\
\hline Blennies & Blennidae sp & 10.4 \\
\hline Brill & Scophthalmus rhombus & 0.3 \\
\hline $\mathrm{Dab}$ & Limanda limanda & 1 \\
\hline Eelpout & Zoarcidae & 0.9 \\
\hline Fifteen spined stickleback & Spinachia spinachia & 6.2 \\
\hline Five-bearded rockling & Gaidropsarus vulgaris & 1.9 \\
\hline Flounder & Platichthys flesus & 1.4 \\
\hline Four-bearded rockling & Enchelyopus cimbrius & 6.6 \\
\hline Gobies & Gobiidae sp & 12.5 \\
\hline Pipefish & Sygnathidae & 1.9 \\
\hline Plaice & Pleuronectes platessa & 0.5 \\
\hline Wrasse & Labridae $s p$ & 4.3 \\
\hline Unidentified Cottidae & Cottidae sp & 2.8 \\
\hline Unidentified flatfish & Hetrosomata $\mathrm{sp}$ & 5 \\
\hline Unidentified fish & & 0.3 \\
\hline Insects & & 0.9 \\
\hline Coleoptera & Dysticus sp & 0.7 \\
\hline Odonata & Ashena sp & 0.2 \\
\hline Crustacean & Crustacean & 6.3 \\
\hline Amphibian & & 3.5 \\
\hline Anuran sp & Rana temporaria, Bufo bufo & 1.9 \\
\hline Newts & Triturus $s p$ & 1.6 \\
\hline Mammalian & & 0.7 \\
\hline Avian & & 3.3 \\
\hline Total & & 100 \\
\hline
\end{tabular}

Number of spraints $=180$

amphibians (3.5\%) and birds (3.3\%) were the most frequent non-fish prey items with insects and mammals occurring at relatively low frequencies. Crustacean remains were mostly Carcinus $s p$, the majority of bird remains were from the Rallidae family and the mammalian remains were predominantly rabbit. A very small number of fish remains were not identifiable through either the reference collection or the published keys, which suggests they are potentially previously unrecorded otter prey items. 
Marine fish constituted the largest component of otter diet throughout the year (Fig. 2). There was no significant seasonal variation in the proportion of marine $\left(F_{3}, 10=0.3\right.$, $p=0.8)$ or freshwater fish $\left(F_{3,10}=0.4, p=0.3\right)$ in otter diet.

There was variation in the composition of otter diet over the study period (Table 2). However, dietary composition in spring was relatively similar to all other seasons, with a mean similarity of $88 \%( \pm 6 \mathrm{SE})$. The mean level of similarity between all seasons was $72 \%( \pm 5 \mathrm{SE})$. Dietary composition in summer 2008 had a lower similarity with all other seasons. There was also a low level of similarity in the composition of diet between winter and summer. The highest similarity in diet was between winter 2007-2008 and spring 2008, when diet was dominated by gobies (winter $\mathrm{RFO}=13.1 \%$, spring $\mathrm{RFO}=18.9 \%$ ) and amphibians (winter $\mathrm{RFO}=6.93 \%$, spring $\mathrm{RFO}=9.43 \%$ ). There was also a high degree of similarity between autumn 2007 and spring 2008. The 10 most important prey types were determined using the overall RFO\% values (Table 3). This excluded 20 prey types, with overall RFO values $<3 \%$. One-way ANOVA showed that the occurrence of eels varied significantly between seasons $\left(F_{3,10}=9.08, p=0.006\right)$ and post hoc tests indicated that eel RFO\% was significantly lower in winter and spring than in summer $(p<0.05)$. No other major prey type displayed significant seasonal variation in occurrence.

\section{Population total niche width}

The mean population TNW calculated for otter diet at Pembrokeshire coastal sites was $0.88( \pm 0.2 \mathrm{SE})$ and trophic niche richness was $20.2( \pm 2.3 \mathrm{SE}$; Table 4$)$. One-way

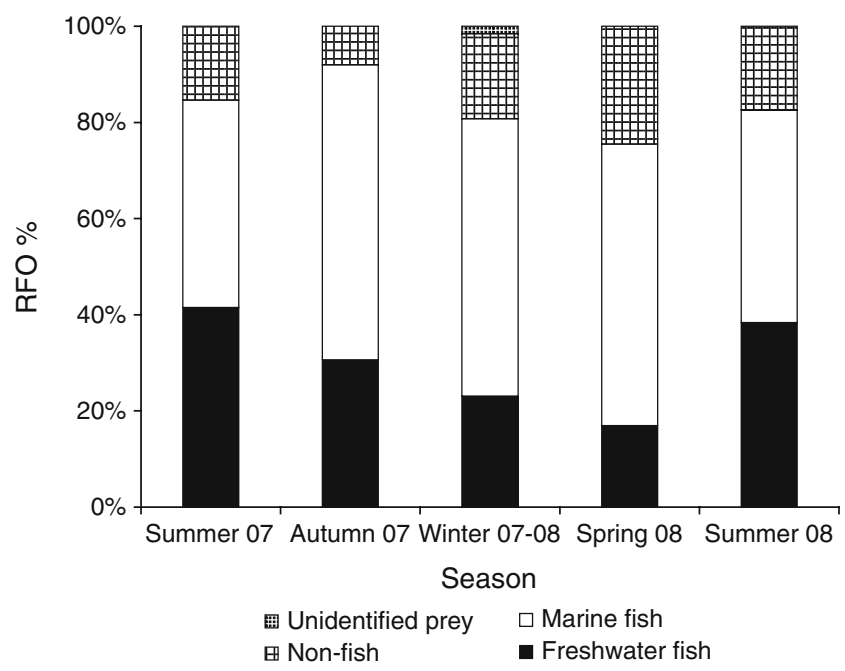

Fig. 2 Seasonal variation in the relative frequency of occurrence (RFO\%) of freshwater fish marine fish non-fish and unidentified prey in otter spraints analysed from Pembrokeshire between July 2007June 2008 (summer $2007 n=23$, autumn $2007 n=35$, winter 2007 $2008 n=53$, spring $2008 n=40$, summer $2008 n=7$ )
ANOVA demonstrated significant seasonal variation in trophic niche width $\left(F_{3,10}=7.1, p=0.01\right)$ and post hoc tests indicated that niche width was narrower in spring than in all other seasons $(p<0.05)$. Comparing the TNW value obtained by this study to those from other locations across the otter's range it can be seen that diet on the Pembrokeshire coast is particularly diverse (Table 5).

\section{Discussion}

Use of the coastal habitats by otter populations

This study confirms that use of the marine environment is widespread in coastal otter populations across Pembrokeshire, with a diet that contains a larger proportion of marine prey than recorded during a preliminary study (Liles 2003a). Marine activity has recently been recorded in otters inhabiting other coastal areas of Wales (Parry and Forman, unpublished data) and England (Jaggs 2009). Whether this represents a current trend for increased use of the marine environment by otters inhabiting coastal areas of the UK is unclear. We propose two possible explanations for the widespread marine activity of otters in Pembrokeshire, and the increasing number of records of marine activity in Wales. Firstly, there is historical evidence that prior to the declines of the twentieth century otters were regularly foraging in the sea off the coastline of Wales (Dillwyn 1848). However, a survey of the Welsh coastal sites undertaken in the 1980s found no evidence of coastal otter activity (Andrew Crawford personal communication). Therefore, as otter populations in Wales recover (Jones and Jones 2004) use of the marine environment may be increasing due to density-dependent effects. Otters are territorial (Kruuk and Moorhouse 1991) and individuals may be displaced into coastal areas when there are high population densities in inland freshwater systems. The last National Otter Survey of Wales returned 97\% (64/66) of sites in Pembrokeshire as positive (Jones and Jones 2004), which suggests that there is potential for intraspecific competition for inland territories. However, this study demonstrates that otters in Pembrokeshire are using marine, freshwater and terrestrial habitats, indicating that otters at coastal sites do not appear to be restricted from accessing inland habitats.

An alternative explanation is that the marine environment has always been a component of the habitat niche of coastal otter populations in the UK, but marine activity has been under-recorded in the past due to difficulties in surveying such terrain. The standardised UK otter survey technique is more appropriately designed for linear riparian systems (Mason and MacDonald 1986), and unfortunately no validated method for monitoring otters in coastal areas exists. Detection probabilities are likely to be lower in 
Table 2 Renkonen's Percentage similarity index values, between seasons, in otter diet on Pembrokeshire 2007-2008

\begin{tabular}{lllll}
\hline Renkonen's Similarity\% & Summer 2007 & Autumn 2007 & Winter 2007-2008 & Spring 2008 \\
\hline Summer 2007 & - & - & - & - \\
Autumn 2007 & 72.0 & - & - & - \\
Winter 2007-2008 & 54.6 & 73.0 & - & - \\
Spring 2008 & 81.8 & 82.4 & 100 & - \\
Summer 2008 & 50.9 & 64.7 & 62.3 & 80.3 \\
\hline
\end{tabular}

coastal areas than in riparian systems, due to the influence of tides that frequently wash away otter signs (Kruuk 1992). Given the increased awareness of otter activity in many coastal areas in Europe (Beja 1991; Heggberget 1993; Kingston et al. 1999; Clavero et al. 2004), the development of a robust otter coastal survey monitoring tool would be timely and of significant utility.

The diet and trophic niche of otters inhabiting coastal areas

Marine fish formed the largest proportion of otter diet throughout the year, clearly indicating that marine prey are an important resource for otters inhabiting coastal areas of Pembrokeshire. In contrast to the study of Clavero et al. (2006), freshwater and terrestrial prey was frequently recorded in spraints collected throughout the year on both rocky and sandy shores. Slow swimming, demersal fish were the most frequent marine and freshwater prey items, indicating that otters foraging on the Pembrokeshire coast caught prey with similar life histories in different habitats. Otters may frequently forage at the demersal zone as it represents an edge, a habitat feature commonly used by foraging carnivores (Andren and Angelstam 1988).

The data indicates that some marine prey items occurred more frequently in otter diet during spring, which could reflect increased use of marine habitats. Gobies, flatfish, blennies, crabs and amphibians, were all frequent prey taken during this most trophically challenging period (Kruuk 2006). Amphibians are relatively plentiful during winter and spring due to this group's tendency to aggregate in large numbers to spawn (Duellman and Trueb 1986); consequently, they often form an important component of otter diet during this period (Weber 1990). It is worthy of note that coastal foraging otters follow this widespread trend in otter ecology. It is now common knowledge that there are significant pressures affecting amphibian populations throughout the world (IUCN 2008). This prey group clearly forms an important component of otter diet at a critical time of year in many areas (the commencement of breeding; Kruuk et al. 1987). The impact of possible widespread amphibian declines on otter reproductive success, and wider trophic cascade effects (Dunne et al. 2002) clearly warrants further urgent investigation.

Otters are believed to be vulnerable during winter, largely due to decreased prey availability and the increased metabolic cost of foraging at lower ambient temperatures (Kruuk et al. 1987; Kruuk and Balharry 1990). This could lead to otters increasing their range, foraging in different habitats or taking alternative prey (Beja 1997; Roche 2001). It is possible that otters switched prey in freshwater areas during winter, in response to the reduced availability of eels. The Renkonen's index values indicated considerable

Table 3 Rank importance and seasonal variation in the relative frequency of occurrence (RFO\%) of the top ten prey types in otter spraints analysed from Pembrokeshire between July 2007-June 2008

\begin{tabular}{|c|c|c|c|c|c|c|}
\hline Prey Category & Summer 2007 & Autumn 2007 & Winter 2007-2008 & Spring 2008 & Summer 2008 & Overall rank \\
\hline Angullidae & 22.8 & 11.7 & 3.1 & 5.7 & 14.3 & 3 \\
\hline Blennidae & 14.0 & 9.5 & 7.7 & 13.2 & 4.8 & 4 \\
\hline Crustacean & 8.8 & 2.9 & 6.2 & 11.3 & 14.3 & $=7$ \\
\hline Cottidae & 5.3 & 6.6 & 5.4 & 3.8 & 0 & 9 \\
\hline Cyprinidae & 7.1 & 7.3 & 8.5 & 5.7 & 0 & $=7$ \\
\hline Gadidae & 5.3 & 13.1 & 6.9 & 7.6 & 9.5 & 5 \\
\hline Gasterosteidae & 7.0 & 12.4 & 14.6 & 5.7 & 14.3 & 1 \\
\hline Gobiidae & 14.0 & 12.4 & 13.1 & 18.9 & 9.5 & 2 \\
\hline Labridae & 3.5 & 1.5 & 4.6 & 5.7 & 4.8 & 10 \\
\hline Pleuronectiformes & 5.3 & 11.00 & 9.2 & 15.7 & 9.5 & 6 \\
\hline
\end{tabular}

Summer $2007 n=23$, autumn $2007 n=35$, winter 2007-2008 $n=53$, spring $2008 n=40$, summer $2008 n=7$ 
Table 4 Seasonal variation in trophic niche richness and total niche width values of the coastal otter population in Pembrokeshire 2007-2008

\begin{tabular}{lllc}
\hline Season & Number of spraints & Niche richness & Total niche width Shannon-Wiener $\left(H^{\prime}\right)$ \\
\hline Summer 2007 & 23 & 22 & 0.95 \\
Autumn 2007 & 35 & 26 & 0.90 \\
Winter 2007-2008 & 54 & 23 & 0.91 \\
Spring 2008 & 40 & 17 & 0.68 \\
Summer 2008 & 7 & 13 & 0.96 \\
Mean $( \pm$ SE) & $31.8 \pm 10.2$ & $20.2 \pm 2.3$ & $0.88 \pm 0.2$ \\
\hline
\end{tabular}

seasonal variation in dietary composition. The low sample size collected in summer 2008 probably contributed to the low level of dietary similarity between this period and other seasons in the study. However, there was a large amount of variation in dietary composition between other seasons as well, notably between summer 2007 and winter 2007-2008. Despites this, only one major prey type showed significant seasonal variation in occurrence in otter diet. Seasonal variations in carnivore diet are likely to reflect seasonal trends in prey availability. A winter decrease in eel predation has been recorded previously and is thought to be due to the over-wintering behaviour of eels reducing their availability to otters (Jenkins et al. 1979). The disparity in dietary composition between winter and summer demonstrates that the composition of otter diet on the Pembrokeshire coast varies seasonally, but the lack of variation in the most frequent prey types indicates that it is the composition of alternative prey that is subject to the most variation, which is a common feature of populations composed of individual specialists (Bolnick et al. 2007).

Table 5 Total niche width values for otter diet, calculated using data provided in selected coastal studies across their range

Study Location Total niche width

Shannon-Wiener $\left(H^{\prime}\right)$

\begin{tabular}{|c|c|}
\hline Eire Murphy and Fairley 1985 & 0.84 \\
\hline Eire (Kingston et al. 1999) & 0.73 \\
\hline Norway (Heggberget 1993) & 0.78 \\
\hline Norway (Heggberget and Moseid 1994) & 0.79 \\
\hline Pembrokeshire Wales & 0.92 \\
\hline Portugal (Beja 1991) ${ }^{\mathrm{a}}$ & 0.70 \\
\hline Portugal (Beja 1997) & 0.69 \\
\hline Scotland (Watson 1978) & 0.81 \\
\hline Scotland (Watt 1995) ${ }^{\mathrm{a}}$ & 0.80 \\
\hline Scotland (Yoxon 1999) & 0.76 \\
\hline Spain (Clavero et al. 2004) & 0.76 \\
\hline Wales (Parry, unpublished) & 0.69 \\
\hline Mean $( \pm \mathrm{SE})$ & $0.77 \pm 0.2$ \\
\hline
\end{tabular}

${ }^{\text {a }}$ Mean niche width value across all sites
The otters had a broad TNW (0.92), a feature of all the coastal otter populations included in the analysis (Table 5), indicating a broad trend for high trophic diversity in coastal otter populations (see also Jędrzejewska et al. 2001). It is interesting to note that the TNW of the Pembrokeshire population was the greatest of all the studies sampled. This can be explained by two factors. Firstly, in contrast to many previous studies of coastal otter populations (Watson 1978; Kruuk and Moorhouse 1990; Heggberget and Moseid 1994; Kingston et al. 1999), otters on the Pembrokeshire coast regularly foraged inland. Secondly, otter diet is thought to reflect the complexity of the surrounding environment (Clavero et al. 2004). The Pembrokeshire coastline is a heterogeneous network of habitats bordered by extensive riparian systems, providing a complex and diverse prey base. Trends in otter trophic diversity may differ between coastal and freshwater habitats due to differences in prey assemblages, particularly in the diversity of fish communities. As opportunistic foragers (Kruuk and Moorhouse 1990; Watt 1995), otters would be expected to have a broad trophic niche where there is a diverse prey base. This study demonstrates that otters living in coastal areas can potentially forage in marine, freshwater and terrestrial habitats, and as such have access to a higher diversity of prey than inland populations (Jędrzejewska et al. 2001). Trophic niche width is also very broad in another coastal foraging otter, the Sea Cat Lutra feline (Medina-Vogel et al. 2004), and this could be a common feature of semi-aquatic carnivores foraging at the freshwater/marine interface.

The broad overall TNW trophic niche width indicates a generalist foraging strategy on the Pembrokeshire coast. However, there was a significant contraction of niche width in spring, which suggests that otters are highly facultative foragers (Glasser 1984) adapting their strategy according to changes in their environment. The observed seasonal trend in TNW contrasts previous dietary studies of otters (Brzeziński et al. 2006; Prigioni et al. 2006a, b) and other carnivore species (Sinclair and Zeppelin 2002; Zalewski 2004; Rosalino et al. 2005), in which niche width undergoes a significant increase during winter. Trends in niche width are usually attributed to seasonal reductions in the availability of preferred prey, as foraging theory predicts 
dietary diversification when preferred prey types are scare (MacArthur and Pianka 1966). There was no significant seasonal variation in the proportion of freshwater prey in otter diet; however, the diversity of freshwater prey may have decreased during spring due to the reduced consumption of eel. This could have contributed to the contraction in TNW during this period.

\section{Conclusions and conservation management implications}

This study demonstrates that use of the marine environment by otters in Pembrokeshire is more frequent and widespread than previously thought. The current and historical prevalence of marine activity in coastal otter populations may be underestimated, as population monitoring surveys usually target freshwater systems and survey techniques have not been developed for coastal areas. There is, therefore, a dearth of longitudinal data from coastal areas. Marine environments would not have escaped the impacts of chemical bioaccumulation, which are considered to be the principal factor behind otter population declines in the UK (Chanin and Jefferies 1978), but the impact is unlikely to have been as severe as in landlocked freshwater habitats. Coastlines could also function as corridors or routes of dispersal, aiding emigration to new freshwater or coastal systems. Determining the current and historical importance of marine habitats is important to elucidate the function of coastal otter populations as sources or sinks of recruitment at the meta-population scale. The marine environment provided the most important prey resources for coastal otter populations in this study, but the consumption of freshwater and terrestrial prey indicates that access to inland habitats by coastal otters is also required. Marine habitats may provide important prey resources, but inland areas provide access to freshwater crucial for drinking and washing (Kruuk 2006), and may contain more suitable breeding habitat (Beja 1996). Consequently, the conservation management of otters in coastal areas should ensure the protection of both marine and freshwater habitat. In particular, an emphasis on maintaining access between marine and freshwater habitats should be incorporated into management plans.

The impact of human disturbance on biodiversity is currently a priority area of research in ecology (Sutherland 2007). In areas such as Pembrokeshire, there is potential for human leisure and industrial activities to unknowingly cause detrimental disturbance to coastal otter populations. Fishing, water sports, boat trips and coasteering are increasingly popular in many coastal areas of the UK. This study illustrates that otter populations utilise coastal habitats in Pembrokeshire more frequently than previously thought. As coastal sites provide important foraging areas and possible breeding sites (Heggberget and Christensen
1994; Liles 2003b; 2009), the potential for disturbance by increased human access to remote coastal sites may be much greater than previously considered. There has certainly been an increase in the number of otter sightings over recent years throughout the study area, suggesting human-otter contact is more frequent. It may also be that otters can habituate to certain low level disturbance at some sites as a trade-off for utilising a profitable resource (Tüzün and Albayrak 2005). We suggest that the reality is likely to be a combination of the two factors, but research is required to quantify the impact, and if necessary to provide mitigation advice and solutions to conservation managers and statutory conservation bodies.

The trophic diversity of otters on the Pembrokeshire coast demonstrates a broad influence on prey communities. The otter's ability to forage on land and in water enables them to effectively exploit coastlines and estuaries. Many of the marine fish consumed in this study use estuaries and shallow coastal waters as nursery areas (Beck et al. 2001) and as such otters are potentially a key predator influencing their populations. Eels were an important prey resource in this study and widespread declines in eel populations (Feunteun 2002) may pose a significant evolutionary challenge to otters in the UK and Ireland, where they have historically been an important prey item (Carss 1995; Kingston et al. 1999). Amphibians are clearly an important food resource; this is of concern given amphibian population declines (IUCN 2008) and the fact that reliance on this vulnerable prey group commonly coincides with periods of otter breeding activity (Kruuk 2006). Loss of amphibians could lead to declines in otter population fitness and force switching to alternative prey items, resulting in trophic cascade effects in coastal and wetland ecosystems. Therefore, the relationship between amphibian prey and otter reproduction needs to be assessed. There is also increasing evidence of individual trophic partitioning within carnivore populations (Estes et al. 2003; Tinker et al. 2008), which has important consequences for conservation management, and therefore, should be investigated in otters.

Acknowledgements We are very grateful to all of the volunteers who gave up their time to make this study possible and to the Pembrokeshire marine SAC group and Pembrokeshire Biodiversity Partnership for planning and co-ordinating the project. Thanks to Rob Parry from the Welsh Wildlife Trust for delivering training workshops for the volunteers and to Geoff Liles for providing advice and access to his reports. This work was funded through the Pembrokeshire Marine SAC Relevant Authorities Group.

Ethical standards declaration We confirm that this study fully complied with current UK law and consideration was paid to the potential impact on the study organisms, prior to commencement. The data providers and NBN Trust bear no responsibility for the further analysis or interpretation of the data and/or information obtained through the NBN gateway. 


\section{Appendix A}

Table 6 Studies included in the comparison of total niche width (TNE) of otter populations across Europe

\begin{tabular}{lcl}
\hline Location & $\begin{array}{c}\text { Total niche width } \\
\text { Shannon-Wiener }\left(H^{\prime}\right)\end{array}$ & Source \\
\hline Eire & 0.84 & $\begin{array}{c}\text { Murphy and Fairley } \\
1985\end{array}$ \\
Eire & 0.73 & Kingston et al. 1999 \\
Norway (Heggberget & 0.78 & Heggberget 1993 \\
1993) & 0.79 & Heggberget and \\
Norway (Heggberget & & Moseid 1994 \\
and Moseid 1994) & 0.92 & Current study \\
Pembrokeshire Wales & 0.70 & Beja 1991 \\
Portugal & 0.69 & Beja 1997 \\
Portugal & 0.81 & Watson 1978 \\
Scotland & 0.80 & Watt 1995 \\
Scotland & 0.76 & Yoxon 1999 \\
Scotland & 0.76 & Clavero et al. 2004 \\
Spain & 0.69 & Parry unpub \\
Wales & & \\
\hline
\end{tabular}

\section{References}

Andren H, Angelstam P (1988) Elevated predation rates as an edge effect in habitat islands. Exp Evid Ecol 69:544-547

Beck M, Heck KL, Able KW, Childers DL, Eggleston DB, Gillanders BM, Halpern B, Hays CG, Hoshino K, Minello TJ, Orth RJ, Sheridan PF, Weinstein MP (2001) The identification, conservation and management of estuarine and marine nurseries for fishes and invertebrates. Bioscience 51:633-641

Begon M, Harper JL, Townsend CR (1996) Ecology: individuals, populations, communities, 3rd edn. Blackwell Scientific Publications, Oxford

Beja PR (1991) Diet of otters (Lutra lutra) in closely associated freshwater, brackish and marine habitats in south-west Portugal. J Zool Lond 225:141-152. doi:10.1111/j.1469-7998.1991.tb03807.x

Beja PR (1996) Temporal and spatial patterns of rest site use by four female otters Lutra lutra along the south-west coast of Portugal. J Zool Lond 239:741-753. doi:10.1111/j.1469-7998.1996.tb05475.x

Beja PR (1997) Predation by marine-feeding otters (Lutra lutra) in south-west Portugal in relation to fluctuating food resources. J Zool Lond 242:503-518. doi:10.1111/j.1469-7998.1997.tb03852.x

Bolnick DI, Svänback R, Araújo MS, Persson L (2007) Comparative support for the niche variation hypothesis that more generalized population are also more heterogeneous. PNAS 104:1007510079. doi:10.1073/pnas.0703743104

Britton RJ, Pegg J, Shepherd JS, Toms S (2006) Revealing the prey items of the otter Lutra lutra in South West England using stomach contents analysis. Folia Zool 55:167-174

Brzeziński M, Romanowski J, Kopcyzński Ł, Kurowicka E (2006) Habitat and seasonal variations in diet of otters, Lutra lutra in eastern Poland. Folia Zool 55:337-348

Carss DN (1995) Foraging behaviour and feeding ecology of the Lutra lutra: a selective review. Hystrix 7:179-194
Carss DN, Elston DA (1996) Errors associated with otter Lutra lutra Faecal analysis II. Estimating prey size distribution from bones recovered in spraints. J Zool Lond 238:319-332. doi:10.1111/ j.1469-7998.1996.tb05397.x

Carss DN, Parkinson SG (1996) Errors associated with otter Lutra lutra faecal analysis. I. Assessing general diet from spraints. J Zool Lond 238:310-317. doi:10.1111/j.1469-7998.1996.tb05396.x

Carss DN, Kruuk H, Conroy JWH (1990) Predation on adult Atlantic salmon Salmo salar L., by otters Lutra lutra (L.) within the River Dee system, Aberdeenshire Scotland. J Fish Biol 37:935-944. doi:10.1111/j.1095-8649.1990.tb03597.x

Chanin PRF, Jefferies DJ (1978) The decline of the otter Lutra lutra L. in Britain: an analysis of hunting records and discussion of causes. Biol J Linn Soc 10:305-328. doi:10.1111/j.1095-8312.1978. tb00018.x

Clavero M, Prenda J, Delibes M (2004) Influence of spatial heterogeneity on coastal otter (Lutra lutra) prey consumption. Ann Zool Fenn 41:551-561

Clavero MJ, Prenda J, Delibes M (2006) Seasonal use of coastal resources by otters: comparing sandy and rocky stretches. Estuar Coast Shelf Sci 66:387-394. doi:10.1016/j.ecss.2005.09.011

Conroy JWH, Watt J, Webb JB (2005) A guide to the identification of theprey remains in otter spraint. The Mammal Society, London

Copp GG, Roche K (2003) Range and diet of Eurasian otters Lutra lutra (L.) in the catchement of the River Lee (south-east England) since re-introduction. Aquat Conserv 13:65-76. doi:10.1002/aqc.561

Crawford A (2003) Fourth otter survey of England 2000-2002. Environment Agency, Bristol

Day MG (1966) Identification of hair and feather remains in the gut and faeces of stoats and weasels. J Zool Lond 148:201-217

Dillwyn LW (1848) Materials for a fauna and flora of Swansea and the neighbourhood. Cambrian office, Swansea

Dunne JA, Williams RJ, Martinez ND (2002) Network structure and biodiversity loss in food webs: robustness increases with connectance. Ecol Lett 5:558-567. doi:10.1046/j.1461-0248.2002.00354.x

Duellman WE, Trueb L (1986) Biology of the Amphibia. McGrawHill, New York

Erlinge S (1968) Food studies on captive otters Lutra lutra L. Oikos 19:259-270

Estes JA, Riedman ML, Staedler MM, Tinker MT, Lyon BL (2003) Individual variation in prey selection by sea otters: patterns, causes and implications. J Anim Ecol 72:44-155. doi:10.1046/ j.1365-2656.2003.00690.x

Feunteun E (2002) Management and restoration of European eel population (Anguilla anguilla): an impossible bargin. Ecol Eng 18:575-591. doi:10.1016/S0925-8574(02)00021-6

Glasser JW (1984) Evolution of efficiencies and strategies of resource exaploitation. Ecology 65:1570-1578. doi:10.1086/284323

Heggberget TM (1993) Marine-feeding otters (Lutra lutra) in Norway: seasonal variation in prey and reproductive timing. J Mar Biol Assoc UK 73:297-312. doi:10.1017/S0025315400032860

Heggberget TM, Moseid KE (1994) Prey selection in coastal Eurasian otters Lutra lutra. Ecography 17:331-338. doi:10.1111/j.16000587.1994.tb00110.x

Heggberget TM, Christensen H (1994) Reproductive timing in Eurasian otters on the coast of Norway. Ecography 17:339-348. doi:10.1111/j.1600-0587.1994.tb00111.x

IUCN (International Union for the Conservation of Nature and Natural Resources) (2008) Conservation International, and Nature-Serve. Global Amphibian Assessment

Jacobsen L, Hansen HM (1996) Analysis of otter (lutra lutra) spraints: Part 1: comparison of methods to estimate prey proportions; Part 2: estimation of the size of prey fish. J Zool Lond 238:167-180. doi:10.1111/j.1469-7998.1996.tb05387.x

Jaggs E (2009) Otter species action plan. Northuberland Biodiversity action plan, Northumberland Wildlife Trust, Newcastle upon Tyne 
Jędrzejewska B, Sidorovich VE, Pikulik MM, Jędrzejewski (2001) Feeding habits of the otter and the American mink in Bialowieza Primeval Forest (Poland) compared to other Eurasian populations. Ecography 24:165-180. doi:10.1034/j.1600-0587.2001. 240207.x

Jenkins D, Walker JGK, McCowan D (1979) Analyses of otter (Lutra lutra) faeces from Deeside, N.E. Scotland. J Zool Lond 187:235244. doi:10.1111/j.1469-7998.1979.tb03946.x

Jones T, Jones D (2004) Otter survey of Wales 2002. Environment Agency, Bristol

Kingston S, O'Connell M, Fairley JS (1999) Diet of Otters Lutra lutra on Inishmore, Aran islands, west coast of Ireland. Biol Environ Proc R Ir Acad B 99B:173-182

Krebs CJ (1989) Ecological methodology. Harper Collins, New York, pp 376-38

Kruuk H (1992) Scent marking by otters (Lutra lutra): signaling the use of resources. Behav Ecol 3:133-140

Kruuk H (2006) Otters ecology, behaviour and conservation. Oxford University Press, Cambridge

Kruuk H, Balharry D (1990) Effects of sea water on thermal insulation of the otter, Lutra lutra. J Zool Lond 220:405-415. doi:10.1111/ j.1469-7998.1990.tb04315.x

Kruuk H, Moorhouse A (1990) Seasonal and spatial differences in food selection by otters (Lutra lutra) in Shetland. J Zool Lond 221:621-637. doi:10.1111/j.1469-7998.1990.tb04021.x

Kruuk H, Moorhouse A (1991) The spatial organization of otters (Lutra lutra) in Shetland. J Zool Lond 224:41-57. doi:10.1111/ j.1469-7998.1991.tb04787.x

Kruuk H, Conroy JWH, Moorhouse A (1987) Seasonal reproduction, mortality and food of otters (Lutra lutra L.) in Shetland. Symp Zool Soc Lond 58:263-278

Liles G (2003a) Otter (Lutra lutra) activity and habitat availability on the Pembrokeshire coast and Milford Haven waterway, within the Pembrokeshire marine candidate special area of conservation. A report for the Pembrokeshire marine SAC relevant authorities group, Milford Haven

Liles G (2003b) Otter breeding sites conservation and management. Conserving Natura 2000 rivers conservation techniques series 5

Liles G (2009) Otter (Lutra lutra) activity on the open coast and islands within the Pembrokeshire Marine Special Area of Conservation. A report to the Pembrokeshire Marine SAC Relevant Authorities Group

MacArthur RH, Pianka ER (1966) On optimal use of a patchy environment. Am Nat 100:603-609. doi:10.1086/282454

Mason CF, Macdonald S (1986) Otters: ecology and conservation. Cambridge University press, Cambridge

Medina-Vogel G, Delgado-Rodriguez C, Alvarez RE, Bartheld JL (2004) Feeding ecology of the marine otter (Lutra felina) in a rocky seashore of the south of Chile. Mar Mamm Sci 20:134 144. doi:10.1111/j.1748-7692.2004.tb01144.x

Miller B, Dugelby B, Foreman D, Martinez del Rio C, Noss R, Phillips M, Reading R, Soul ME, Terborgh J, Wilcox L (2001) The importance of large carnivores to healthy ecosystems. Endanger Species Update 18:202-210

Miranda R, Escala MC (2002) Guía de identificación de restos óseos de los Ciprínidos presentes en España. Serie Zool 28:1-237

Murphy KP, Fairley JS (1985) Food and sprainting places of otters on the west coast of Ireland. Ir Nat J 21:469-508

NBN (2010) Sourced through the NBN Gateway website using data collected during the mammal recording scheme held by the
Biological Records Centre. Updated 20/05/2008. Available at: http://data.nbn.org.uk/*. Accessed on Sept 24, 2010

Oliveira M, Sales-Luís T, Duarte A, Nunes SF, Carneiro CT, Tenreiro CT, Tenreiro R, Santos-Reis M, Tavares ML, Vilela CL (2008) First assessment of microbial diversity in faecal microflora of Eurasian otter (Lutra lutra Linnaeus, 1758) in Portugal. Eur J Wildl Res 54:245-25. doi:10.1007/s10344-007-0137-8

Prigioni C, Balestrieri A, Remonti L, Gargaro A, Priore G (2006a) Diet of the Eurasian otter (Lutra lutra) in relation to freshwater habitats and alien fish species in southern Italy. Ethol Ecol Evol 18:307-320

Prigioni C, Remonti L, Balestrieri A, Sgrosso S, Priore G, Mucci N, Randi E (2006b) Estimation of European otter (Lutra lutra) population size by fecal DNA typing in southern Italy. J Mamm $87: 855-858$

Project Management Support Services (2006) Wales marine energy site selection. Welsh Development Agency

Roche K (2001) Sprainting behaviour, diet and foraging strategy of otters (Lutra lutra L.) in the Třebon Biosphere Reserve (Czech Republic). $\mathrm{PhD}$ thesis, Academy of the Czech Republic Institute of Vertebrate Biology in Brno

Rosalino LM, Loureiro F, Macdonald DW, Santos-Reis M (2005) Dietary shifts of the badger (Meles meles) in Mediterranean woodlands: an opportunistic forager with seasonal specialisms. Mamm Biol 70:12-23. doi:10.1078/1616-5047-00172

Ruiz-Olmo J, Loy A, Cianfrani C, Yoxon P, Yoxon G, de Silva PK, Roos A, Bisther M, Hajkova P,. Zemanova B (2008) Lutra lutra. In: IUCN 2009. IUCN red list of threatened species. Version 2009.2. Available at: www.iucnredlist.org. Accessed on March 13, 2010

Sargeant BL (2007) Individual foraging specialization: niche width versus niche overlap. Oikos 116:1431-1437

Sinclair EH, Zeppelin TK (2002) Seasonal and spatial differences in diet in the Western stock of steller sea lions (Eumetopias jubatus). J Mamm 83:973-990. doi:10.1644/1545-1542(2002) $083<0973$ :SASDID $>2.0$. CO 2

Sutherland WJ (2007) Future directions in disturbance research. Ibis 149:120-124. doi:10.1111/j.1474-919X.2007.00673

Tinker MT, Bentall G, Estes JA (2008) Food limitation leads to behavioural diversification and dietary specialization in sea otters. PNAS 105:560-565. doi:10.1073/pnas.0709263105

Tüzün I, Albayrak I (2005) The effect of disturbances to habitat quality on otter (Lutra lutra) activity in the River Kizilirmak (Turkey): a case study. J Zool Turk 29:327-335

Watt J (1995) Seasonal and are related variations in the diet of otters Lutra lutra on Mull. J Zool Lond 237:179-194. doi:10.1111/ j.1469-7998.1995.tb02757.x

Watson H (1978) Coastal otters in Shetland. Vincent Wildlife Trust, London

Wheeler A (1969) The fishes of the British Isles and North-West Europe. Macmillan, London

Weber JM (1990) Seasonal exploitation of amphibians by otters (Lutra lutra) in north-east Scotland. J Zool Lond 220:641-651. doi:10.1111/j.1469-7998.1990.tb04740.x

Yoxon P (1999) The effect of Geology on the Distribution of the Eurasian Otter (Lutra lutra) on the Isle of Skye, Scotland, PhD thesis, Open University

Zalewski A (2004) Geographical and seasonal variation in food habits and prey size of European Pine Marten. In: Harrison DJ, Fuller AK, Proulx G (eds) Martens and fishers (Martes) in humanaltered environments. Springer Science, New York 